\title{
Stimulation of renin secretion by potassium-channel activation with cromakalim
}

\author{
C.P.Ferrier, A. Kurtz, P. Lehner, S. G. Shaw, C. Pusterla, H. Saxenhofer, and P. Weidmann \\ Medizinische Poliklinik, University of Berne, Berne and Institute of Physiology, University of Zurich, Zurich, Switzerland
}

Summary. The cardiovascular and endocrine profile of cromakalim has been studied in 8 healthy men (age $25 \pm 2$ years; $\bar{X}$ SEM) and its influence on renin release from cultured rat juxtaglomerular cells in vitro has also been examined. According to a double-blind, randomized sequence the subjects received placebo or cromakalim $1 \mathrm{mg}$ as a single daily oral dose for 5 days.

Compared to placebo, cromakalim significantly increased plasma renin activity $(+122 \%$; from 1.73 to $\left.3.87 \mathrm{ng} \mathrm{AI} \cdot \mathrm{ml}^{-1} \cdot \mathrm{h}^{-1}\right)$, angiotensin II $(+105 \%$; from 5.1 to $10.5 \mathrm{pg} \cdot \mathrm{ml}^{-1}$ ), and norepinephrine $(+61 \%)$ levels, and heart rate $(+8 \%)$. Plasma aldosterone, blood pressure and indices of the electrolytefluid volume state were unchanged.

Cromakalim in vitro stimulated renin release, from 9.9 to $36.5 \mathrm{ng} \mathrm{AI} \cdot \mathrm{h}^{-1} \cdot 30 \mathrm{~min} \cdot \mathrm{mg}$ cell protein, from juxtaglomerular cells.

It appears that the presumed $\mathrm{K}^{+}$-channel activator cromakalim increases renin release in vivo at least in part by direct stimulation of renal juxtaglomerular cells.

Key words: cromakalim; renin release, juxtaglomerular cells, membrane potential, hyperpolarisation, potassium channels, angiotensin II, norepinephrine

Cromakalim (BRL 34915) is a novel benzopyran derivative [1], which has recently been found to produce smooth muscle relaxation in vitro by a mechanism involving cell membrane hyperpolarisation [2]. This effect of cromakalim is thought to result from its ability to open potassium $\left(\mathrm{K}^{+}\right)$-channels, which are normally closed at resting membrane potential, and to activate the conductance of $\mathrm{K}^{+}$-ions [2-5]. Cromakalim has been found to lower blood pressure
(BP) in animals with certain experimental forms of hypertension [6], as well as in hypertensive men [7]. The mechanism underlying the cardiovascular response requires further clarification, and the effects of cromakalim on catecholamines and the reninangiotensin-aldosterone system have not been elucidated. Therefore, the first part of the present study was undertaken to investigate the cardiovascular and endocrine profile of cromakalim in normal humans.

The major site of renin production, namely, the renal juxtaglomerular (JG) cell, is a modified vascular smooth muscle cell (VSMC) [8], and its electrical properties have been found to be identical with VSMC [9]. Experimental evidence suggests that the membrane potential of renal JG epitheloid cells is an important determinant of renin secretion $[10,11]$. Considering the hyperpolarizing action of cromakalim on VSCM, the second part of the study was designed to investigate the influence of cromakalim on renin secretion by JG cells in vitro.

\section{Subjects and methods}

\section{Studies in humans}

Eight healthy non-obese male volunteers, ranging in age from 23 to 27 years (mean (SD), 25 (2) years) were investigated. All had a BP consistently below $140 / 90 \mathrm{~mm} \mathrm{Hg}$, none had evidence of any disease, and none was taking any drugs. Written informed consent was obtained from all subjects.

Cromakalim (Beecham-Wülfing, FRG), $1 \mathrm{mg}$, or placebo were administered double-blind in randomized sequence, as a single oral dose each morning for 5 days. The subjects consumed a fixed diet with a daily intake of 130 meq sodium and $75 \mathrm{meq}$ potassium during the 2 study phases, which were separated by an interval of 3 weeks. Alcohol was avoided. The subjects were instructed to maintain their usual physical activity. Possible side-effects of cromakalim were evaluated by a standard self-administered questionnaire, which was completed at the end of each phase. 
Table 1. Basal values of blood pressure, electrolytes and endocrine variables in normal subjects on placebo and during treatment with cromakalim

\begin{tabular}{|c|c|c|c|c|}
\hline \multirow{2}{*}{$\frac{\text { Variable }}{n}$} & \multicolumn{2}{|c|}{ Placebo } & \multicolumn{2}{|c|}{ Cromakalim } \\
\hline & & & & \\
\hline Weight (kg) & 63 & $(2)$ & 63 & (2) \\
\hline $\begin{array}{l}\text { Heart rate, supine } \\
\text { (beats } \cdot \min ^{-1} \text { ) }\end{array}$ & 60 & (1) & $65^{\mathrm{a}}$ & (2) \\
\hline \multicolumn{5}{|l|}{$\begin{array}{l}\text { Blood pressure, supine } \\
(\mathrm{mm} \mathrm{Hg})\end{array}$} \\
\hline Systolic & 112 & (3) & 112 & (4) \\
\hline Diastolic & 65 & (2) & 63 & $(2)$ \\
\hline Mean & 80 & (2) & 80 & (2) \\
\hline \multicolumn{5}{|l|}{ Plasma } \\
\hline $\begin{array}{l}\text { Renin activity } \\
\left(\text { ng } \mathrm{AI} \cdot \mathrm{ml}^{-1} \cdot \mathrm{h}^{-1}\right)\end{array}$ & 1.73 & $(0.25)$ & $3.87^{\mathrm{b}}$ & $(0.36)$ \\
\hline Angiotensin $I I\left(\mathrm{pg} \cdot \mathrm{ml}^{-1}\right)$ & 5.1 & $(0.7)$ & $10.5^{\mathrm{a}}$ & $(2.3)$ \\
\hline Aldosterone $\left(\mathrm{ng} \cdot \mathrm{dl}^{-1}\right)$ & 9.2 & $(2.0)$ & 8.5 & (1.1) \\
\hline Adrenaline $\left(\mathrm{ng} \cdot \mathrm{dl}^{-1}\right)$ & 2.47 & $(0.5)$ & 3.23 & $(1.00)$ \\
\hline $\begin{array}{l}\text { Noradrenaline } \\
\left(\mathrm{ng} \cdot \mathrm{dl}^{-1}\right)\end{array}$ & 11.5 & $(2.0)$ & $18.5^{\mathrm{a}}$ & $(2.0)$ \\
\hline Dopamine $\left(\mathrm{ng} \cdot \mathrm{dl}^{-1}\right)$ & 0.58 & $(0.15)$ & 0.64 & $(0.15)$ \\
\hline $\operatorname{irANP}\left(\mathrm{pg} \cdot \mathrm{ml}^{-1}\right)$ & 31 & $(6)$ & 33 & $(10)$ \\
\hline Sodium $\left(\mathrm{mmol} \cdot \mathrm{1}^{-1}\right)$ & 140 & $(0.7)$ & 140 & $(0.5)$ \\
\hline Potassium $\left(\mathrm{mmol} \cdot \mathrm{1}^{-1}\right)$ & 4.01 & $(0.1)$ & 4.00 & $(0.1)$ \\
\hline $\begin{array}{l}\text { Total calcium } \\
\left(\mathrm{mmol} \cdot \mathrm{1}^{-1}\right)\end{array}$ & 2.28 & $(0.01)$ & 2.28 & $(0.01)$ \\
\hline Creatinine $\left(\mu \mathrm{mol} \cdot 1^{-1}\right)$ & 94 & (3) & 94 & (5) \\
\hline $\begin{array}{l}\text { Urinary sodium } \\
\left(\mathrm{mmol} \cdot 24 \mathrm{~h}^{-1}\right)\end{array}$ & 138 & (10) & 118 & (14) \\
\hline $\begin{array}{l}\text { Urinary potassium } \\
\left(\mathrm{mmol} \cdot 24 \mathrm{~h}^{-1}\right)\end{array}$ & 61 & (4) & 54 & (4) \\
\hline $\begin{array}{l}\text { Creatinine clearance } \\
\left(\mathrm{ml} \cdot \min ^{-1} \cdot 1.73 \mathrm{~m}^{-2}\right)\end{array}$ & 112 & (8) & 106 & (8) \\
\hline
\end{tabular}

On Day 4 of each study phase, a 24-h urine sample for determination of sodium, potassium and creatinine excretion rates was collected, and body weight was recorded. On Day 5, after overnight fasting, the last capsule was ingested $2 \mathrm{~h}$ prior to the following procedure. After an equilibration period of $1 \mathrm{~h}$ in the supine position, with a slow intravenous infusion of $5 \%$ dextrose solution $(6 \mathrm{ml} / \mathrm{h})$, basal BP and heart rate (HR) were measured. Blood samples were taken from an indwelling cannula inserted 30-60 min previously in the arm contralateral to the infusion, for determination of plasma renin activity (PRA), angiotensin II (ANG II), aldosterone, norepinephrine (NE), epinephrine, dopamine, immunoreactive atrial natriuretic peptide (irANP), sodium, potassium, calcium and creatinine levels. The basal samples were collected between 08.00 and $08.30 \mathrm{~h}$. The dextrose solution was then replaced by a solution of ANG II (Hypertensin CIBA) in 5\% dextrose, which was infused at approximately 2,4 , and $10 \mathrm{ng}$. $\mathrm{kg}^{-1} \cdot \mathrm{min}^{-1}$. During the last 10 min of each infusion step, BP and HR were recorded every min. At the end of each infusion step blood was collected from the contralateral arm for determination of PRA, plasma aldosterone, and ANGII. At the last ANGII-infusion step, blood samples for the determination of plasma irANP, sodium and potassium were also collected.

BP was measured with standard cuff and sphygmomanometer; the mean of 3 readings was used for analysis. During the infu- sion study, BP was monitored with an automatic recorder (Tonoprint SK Gmb, Jungingen, FRG); the mean of 9 to 11 measurements was used for analysis. Mean arterial BP was calculated as the sum of the diastolic and one-third of the pulse pressure. Plasma and urinary sodium and potassium were measured by flame photometry; calcium and creatinine by Greiner autoanalyser (Greiner SA, Langenthal, Switzerland); PRA, plasma ANGII, aldosterone and irANP by radioimmunoassay [12-15] and plasma catecholamines by high performance liquid chromatography with electrochemical detection (Waters, Milford, MA; [16]. The methods have been reported previously [17-19].

Statistical analysis was performed with the Statistical Analysis System (Version 5.0, Cary, NC, USA). Methods included paired (2-tailed) Student's $t$-test, regression analysis, and analysis of variance. Since natural logarithmic transformation rather than absolute values followed a Gaussian distribution, the natural logarithms of PRA, ANGII, aldosterone, catecholamine levels and the doses of infused ANGII were used for statistical analysis.

\section{Studies of juxtaglomerular cell culture in vitro}

Primary cell cultures of rat JG cells were prepared as single cell suspensions by perifusion of rat kidneys with citrate, dissociation with trypsin and collagenase, and sieving through a $22 \mu \mathrm{m}$ screen, as previously described $[20,21]$. The cells were further separated on a $25 \%$ isoosmotic Percoll gradient, cells with a density of $1.06 \mathrm{~g} / \mathrm{ml}$ being used for culture. On the second day of culture, about $90 \%$ of the attached cells are JG cells, as judged by specific immunostaining for rat renin [21]. Renin release from the cells was measured as the linear increase in renin activity of the supernatant in the absence and presence of cromakalim for $30 \mathrm{~min}$. The culture medium was replaced with prewarmed, Hepes buffer solution $\left(132 \mathrm{mM} \mathrm{NaCl}, 5 \mathrm{mM} \mathrm{KCl}, 0.8 \mathrm{mM} \mathrm{MgSO}_{4}, 2 \mathrm{mM} \mathrm{CaCl}_{2}\right.$, $10 \mathrm{mM}$ sodium acetate, $2 \mathrm{mM} \mathrm{NaH}_{2} \mathrm{PO}_{4}, 10 \mathrm{mM}$ glucose, $20 \mathrm{mM}$ Hepes, pH 7.2) and the culture dishes were placed on a heating block at $37^{\circ} \mathrm{C}$. The time-dependent increase in renin activity in the supernatant was then monitored. Renin activity was determined by its ability to generate angiotensin I from the plasma of bilaterally nephrectomized rats [21]. At the end of the experiments, the cells were lysed by addition of $1 \mathrm{~N} \mathrm{NaOH}$ and cell protein was determined by the method of Lowry [22].

\section{Results}

\section{Studies in humans}

Compared with placebo conditions, cromakalim administered orally over 5 days did not significantly modify indices of the electrolyte-fluid volume state, such as body weight, plasma sodium, potassium and calcium levels, 24-h urine sodium and potassium excretion rates, or creatinine clearance (Table 1); BP also was unchanged. However, cromakalim produced a significant increase in PRA $(+122 \%$, $p<0.001)$, plasma ANGII $(+105 \%, p<0.01)$, NE $(+61 \%, p<0.01)$, and heart rate $(+8 \%, p<0.01$, while plasma epinephrine, dopamine, aldosterone and irANP levels were unaltered.

During ANGII infusion and treatment either with placebo or cromakalim, the plasma ANGII 
Table 2. Diastolic blood pressure, heart rate and endocrine variables before and during angiotensin II infusion in subjects on placebo and after administration of cromakalim

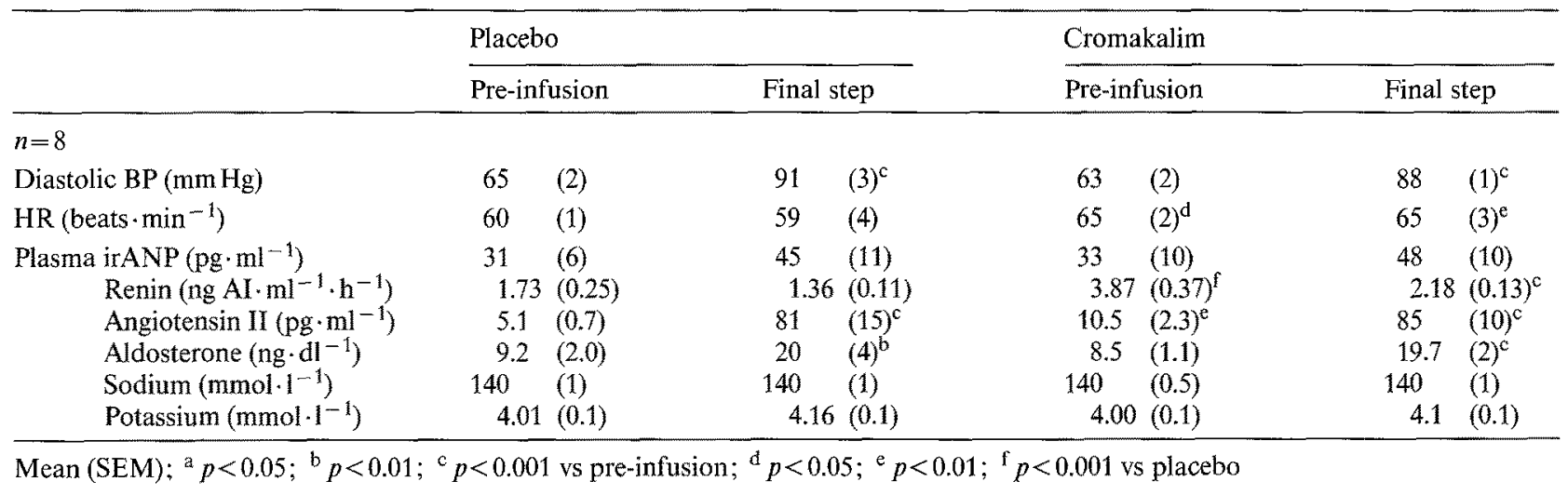

level was correlated with the ANGII infusion rate $(r=0.81$ and $r=0.89$, respectively; $p<0.001$ ). The increase in diastolic BP was correlated with the concomitant changes in plasma ANGII level $(r=0.76$ and 0.70 , respectively; $p<0.001$ ), and so was plasma aldosterone ( $r=0.41$ and 0.74 , respectively; $p<0.05$ to $p<0.001$ ). The plasma ANGII-BP and ANGII-aldosterone response curves (Fig. 1) during ANGII infusion were not significantly modified by cromakalim. The mean values of variables measured before and during the final step of the ANGII infusion are shown in Table 2 . The infusion significantly $(p<0.01)$ decreased PRA during administration of cromakalim, but not during administration of placebo (Fig.2). Plasma irANP tended to increase slightly but not significantly during ANGII infusion in both phases of the study.

During administration of cromakalim, 3 subjects complained of slight headache. No other symptoms were noted.

\section{Studies of juxtaglomerular cell cultures}

A possible direct effect of cromakalim on renin secretion was assessed on rat renal JG cells. As shown in Fig. 3, cromakalim concentration-dependently stimulated renin secretion from $9.9(0.9)$ to 36.6 (2.5) $\mathrm{ng} \mathrm{AI} \cdot \mathrm{h}^{-1} \cdot 30 \mathrm{~min} \cdot \mathrm{mg}$ cell protein $(\mathrm{SEM}$, $n=6, p<0.01$ ).

\section{Discussion}

The results demonstrate that the presumed $\mathrm{K}^{+}$channel activator and vasorelaxant cromakalim $1 \mathrm{mg} /$ day for 5 days stimulated the renin-angiotensin system in normal humans and directly activated the release of renin from rat JG cells in vitro.

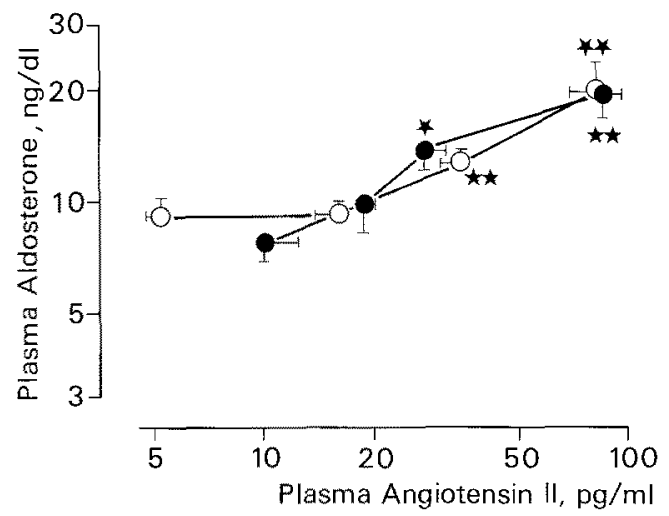

Fig. 1. Relationship between plasma angiotensin II and aldosterone levels before and during angiotensin II infusion on placebo $(O)$ and during administration of cromakalim $(\Theta)$ in 8 men. (Mean (SEM); ${ }^{*} p<0.05,{ }^{* *} p<0.01$ vs basal value (by analysis of variance)

Mechanisms which are known to activate the secretion of renin in humans include an acute fall in $B P$, salt depletion, enhanced sympathetic discharge [23], and potassium retention [24]. BP and indices of the electrolyte-fluid volume state here were unchanged and, therefore, could not account for the renin-angiotensin stimulation by cromakalim. Circulating irANP, a potential inhibitor of renin release $[20,25]$, also was unaltered. On the other hand, the constellation of increased HR and plasma NE levels during cromakalim treatment is consistent with the possibility that enhanced sympathetic outflow contributed at least in part to activation of the reninangiotensin system in vivo. Considering the vasodilating properties of cromakalim in experimental animals [6], its effect on plasma NE and heart rate in humans may well be mediated by a baroreflex.

Since basal plasma aldosterone levels were unchanged or were even slightly decreased in the presence of renin-angiotensin stimulation, induced by cromakalim the possibility of an inhibitory inter- 


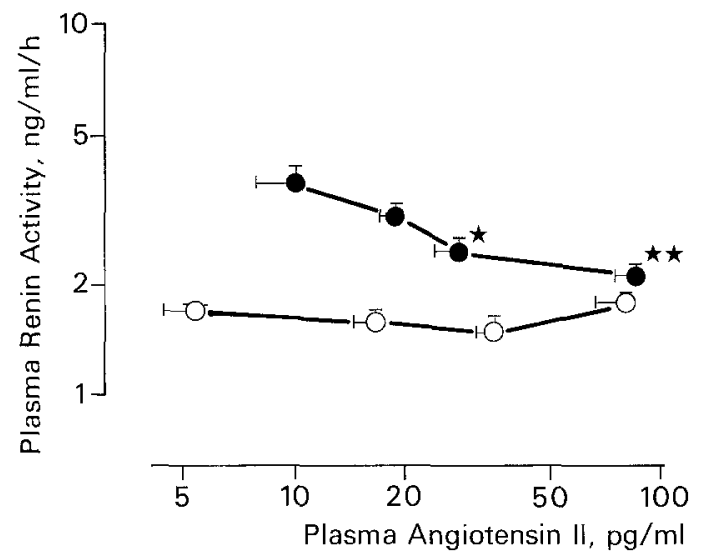

Fig. 2. Relationship between plasma angiotensin II and renin activity before and during angiotensin II infusion on placebo $(O)$ and during administration of cromakalim $(\bullet)$ in 8 men. (Mean (SEM); $* p<0.01, * * p<0.001$ vs basal value (by analysis of variance)

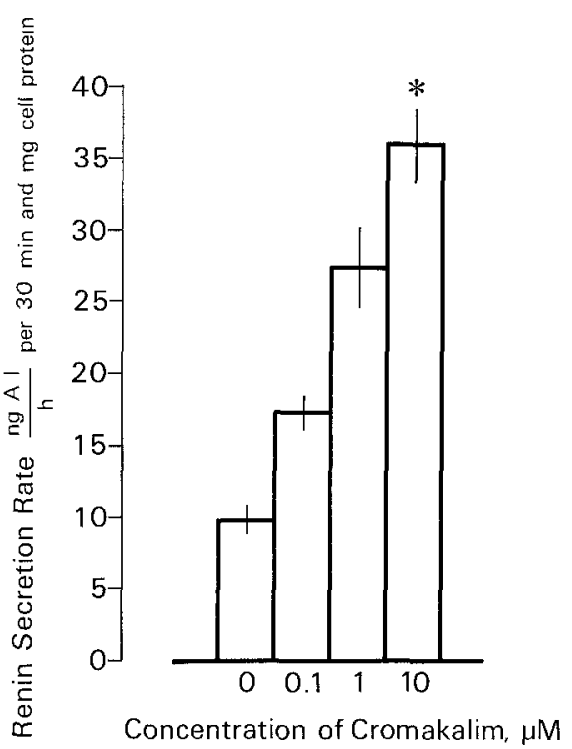

Fig.3. Effect of cromakalim on renin release from rat juxtaglomerular cell culture. $(n=6$, Mean (SEM);* $*<0.001$ vs basal value

action of cromakalim with basal aldosterone secretion deserves consideration. However, the responsiveness of aldosterone to ANGII was found not to be altered during administration of cromakalim.

The cromakalim-induced stimulation of renin was blunted during acute hyperangiotensinaemia in the normal humans. This indicates that the physiological feedback inhibition of renin release by ANGII [26] is not impaired by cromakalim. In fact, ANGII infusion during placebo administration, if anything, produced a less distinct and statistically insignificant decrease in PRA, probably due to the lower basal PRA. Previous studies have demonstrated that the degree of renin inhibition during
ANGII infusion depends on the pre-infusion PRA level [27].

The in vitro study revealed that cromakalim was able directly to stimulate JG renin secretion by a mechanism independent of the sympathetic nervous system. Cromakalim has been found to hyperpolarize VSMC by activation of $\mathrm{K}^{+}$channels [2]. Renal JG cells are modified VSMC [8] and have similar electrical properties to those of typical VSMC [9]. Renin release from JG cells is inversely related to the intracellular concentration of calcium [28]. Indirect evidence suggests that voltage-gated calcium channels are involved in the regulation of calcium in JG cells [28]. Thus, it is tempting to speculate that the mechanism of cromakalim-induced renin secretion may perhaps involve hyperpolarisation of JG granular cells.

Although the exact cellular interactions will have to be clarified in future experiments, the in vitro results strongly suggest that a direct action on renal juxtaglomerular cells is a likely explanation for the effect of cromakalim on renin secretion in vivo.

Acknowledgements. The study was supported in part by the Swiss National Foundation. The authors thank the Beecham-Wülfing $\mathrm{GmbH} \& \mathrm{Co}$. KG for supporting the studies and Mrs. G. Haueter, Miss R. Mosimann, Miss E. Oldenberg, Mrs. S. Schwenk, Miss B. de Breuyn, Miss R. Takkinen, Miss J.Boden, and Mrs. J.Grand for technical assistance.

\section{References}

1. Ashwood VA, Buckingham RE, Cassidy F, Evans JM, Faruk EA, Hamilton TC, Nash DJ, Stemp G, Willcocks K (1986) Synthesis and antihypertensive activity of 4-(cyclic amido)-2H-1-benzopyrans. J Med Chem 29: 2194-2201

2. Hamilton TC, Weir SW, Weston AH (1986) Comparison of the effects of BRL 34915 and verapamil on electrical and mechanical activity in rat portal vein. $\mathrm{Br} \mathrm{J}$ Pharmacol 88: 103-111

3. Weir SW, Weston AH (1986) Effect on apamin on responses to BRL 34915, nicorandil and other relaxants in the guinea-pig taenia caeci. Br J Pharmacol 88: 113-120

4. Fujii K (1987) An electrophysiological investigation of the mechanism of action of BRL 34915 on the guinea-pig bladder. Proc Br Pharmacol Soc Meeting, Oxford, p 190

5. Foster CD, Brading AF (1987) The effect of potassium channel antagonists on the BRL 34915 activated potassium channel in guinea-pig bladder. Proc Br Pharmacol Soc Meeting, Oxford, p 191

6. Buckingham RE, Clapham JC, Hamilton TC, Longman SD, Norton J, Poyser RH (1986) BRL 34915, a novel antihypertensive agent: Comparison of effects on blood pressure and other haemodynamic parameters with those of nifedipine in animal models. J Cardiovasc Pharmacol 8: 798-804

7. Vanden Burg MJ, Arr Woodward SM, Stewart-Long P, Tasker T, Pilgrim AJ, Dews IM, Fairhurst G (1987) Potassium channel activators: antihypertensive activity and adverse effect profile of BRL 34915. J Hypertension 5 [Suppl 5]: S193-S195 
8. Barayas L (1979) Anatomy of juxtaglomerular apparatus. Am J Physiol 237 [Suppl 5]: F333-F343

9. Bührle CP, Scholz H, Hackental E, Nobiling R, Taugner R (1986) Epithelioid cells: Membrane potential changes induced by substances influencing renin secretion. Mol Cell Endocrinol 45: 37-47

10. Fishman MC (1976) Membrane potential of juxtaglomerular cells. Nature $260: 542 \cdots 544$

11. Fray JCS (1980) Stimulus-secretion coupling of renin. Role of hemodynamic and other factors. Circ Res 47: 485-492

12. Sealey JE, Gerten-Banes J, Laragh JH (1972) The renin system: Variations in man measured by radioimmunoassay or bioassay. Kidney Int 1: 240-253

13. Düsterdieck GO, McElwee G (1971) Estimation of angiotensin II concentration in human plasma by radioimmunoassay: some applications to physiological and clinical states. Eur J Clin Invest $2: 32-38$

14. Malvano R, Gandolfi C, Gianessi D, Giannotti P, Grosso P (1976) Radioimmunoassay of aldosterone in crude plasma extracts. J Nucl Biol Med 20: 37-44

15. Shaw SG, Weidmann $P$ (1988) Potential pitfalls in the radioimmunoassay of physiological plasma levels of atrial natriuretic peptide. Z Kardiol 77 [Suppl 2]: 26-30

16. Smedes F, Kraak JC, Poppe H (1982) Simple and fast solvent extraction system for selective and quantitative isolation of adrenaline, noradrenaline and dopamine from plasma and urine. J Chromatogr $231: 25-39$

17. Weidmann $P$, Beretta-Piccoli C, Ziegler WH, Keusch $G$, Glück Z, Reubi FC (1978) Age versus urinary sodium for judging renin, aldosterone, and catecholamine levels. Studies in normal subjects and patients with essential hypertension. Kidney Int 14:619-628

18. Gerber A, Weidmann P, Marone C, Uehlinger DE, Riesen W (1985) Cardiovascular and metabolic profile during intervention with urapidil in humans. Hypertension 7:963-971

19. Uehlinger DE, Zaman T, Weidmann $P$, Shaw $S$, Gnädinger MP (1987) Pressure dependence of atrial natriuretic peptide during norepinephrine infusion in humans. Hypertension 10: $249-253$

20. Kurtz A, Della Bruna R, Pfeilschifter J, Taugner R, Bauer C
(1986) Atrial natriuretic peptide inhibits renin release from juxtaglomerular cells by a cGMP-mediated process. Proc Natl Acad Sci USA 83: 4769-4773

21. Kurtz A, Pfeilschifter J, Hutter A, Bührle C, Nobiling R, Taugner R, Hackenthal E, Bauer C (1986) Role of protein kinase Cin inhibition of renin release caused by vasoconstrictors. Am $\mathbf{J}$ Physiol 250: C563-C571

22. Lowry OH, Rosenbrough NJ, Farr AL, Randall RJ (1951) Protein measurement with the folin phenol reagent. I Biol Chem 193: 265-275

23. Keeton TK, Campbell WB (1981) The pharmacologic alteration of renin release. Pharmacol Rev 31: 81-227

24. Brunner HR, Baer L, Sealey JE, Ledingham JGG, Laragh JH (1970) The influence of potassium administration and of potassium deprivation on plasma renin in normal and hypertensive subjects. J Clin Invest 49:2128-2138

25. Struthers AD, Anderson JV, Payne N, Causon RC, Slater JDH, Bloom SR (1986) The effect of atrial natriuretic peptide on plasma renin activity, plasma aldosterone, and urinary dopamine in man. Eur J Clin Pharmacol 31:223-226

26. Blair-West JR, Coghlan JP, Denton DA, Funder JW, Scoggins BA, Wright RD (1971) Inhibition of renin secretion by systemic and intrarenal angiotensin infusion. Am J Physiol 220: 1309-1315

27. Beretta-PiccoliC, Weidmann P, Keusch G, Glück Z, Grimm M, Meier A, Minder I (1980) Responsiveness of circulating catecholamines, renin and aldosterone to angiotensin II.Studies in normal and hypertensive man. Miner Electrolyte Metab 4: $137-148$

28. Kurtz A (1986) Intracellular control of renin release - An overview. Klin Wochenschr 64: 838-846

Received: May 27, 1988

accepted in revised form: November 9, 1988

Prof. P. Weidmann

Medizinische Universitätspoliklinik

Freiburgstrasse 3

CH-3010 Berne, Switzerland 